\title{
Intra-Operative Mitomycin-C as Adjuvant Therapy in External and Endonasal Dacryocystorhinostomy: Systematic Review and Meta-Analysis
}

\author{
Tamata T. S. Sousa - Silvana A. Schellini - Roberta L. F. S. Meneghim •
}

Antonio J. M. Cataneo

Received: March 19, 2020 / Published online: April 27, 2020

(C) The Author(s) 2020, corrected publication 2021

\section{ABSTRACT}

Purpose: To evaluate the effect of mitomycin-C (MMC) on the success of external (Ex-DCR) or endoscopic dacryocystorhinostomy (En-DCR).

Method: A systematic review of randomized clinical trials of Ex- or En-DCR with and without the use of MMC to treat primary acquired nasolacrimal duct obstruction (NLDO) was done. Two authors independently searched six databases from 1990 to 2019, using the terms "dacryocystorhinostomy" and "mitomycin-C."

Digital Features To view digital features for this article go to https://doi.org/10.6084/m9.figshare.12124326.

T. T. S. Sousa $\cdot$ S. A. Schellini $(\bowtie) \cdot R$.

L. F. S. Meneghim

Department of Ophthalmology, Faculdade de

Medicina, Universidade Estadual Paulista Julio de

Mesquita Filho, Botucatu, São Paulo, Brazil

e-mail: sschellini@gmail.com

\section{A. J. M. Cataneo}

Department of Surgery, Faculdade de Medicina, Universidade Estadual Paulista Julio de Mesquita Filho, Botucatu, São Paulo, Brazil
Statistical and meta-analyses were performed using RevMan 5.3 software.

Results: Twenty-seven studies involving 2158 surgeries were included in this systematic review. The Ex-DCR group comprised 14 studies [odds ratio (OR): $2.74 ; 95 \%$ confidence intervals (CI) 1.54-4.87; $\left.I^{2}=30 \%\right]$, while the En-DCR group 13 studies (OR: 1.69; 95\% CI 1.21-2.37; $\left.I^{2}=0 \%\right)$. The use of MMC slightly increased the success rate of Ex- or En-DCR (OR: 2.1; 95\% CI $1.52-2.9 ; I^{2}=14 \%$ ).

Conclusion: The intraoperative use of MMC is safe and slightly improves the success rate of Exor En-DCR. However, the evidence was very weak.

Keywords: Endoscopic dacryocystorhinostomy; External dacryocystorhinostomy; Metaanalysis; Mitomycin-C; Nasolacrimal duct obstruction; Success; Systematic review 


\section{Key Summary Points}

Why carry out this study?

Mitomycin-C (MMC) has antifibrotic effects on the nasal mucosal fibroblasts and can improve success of external or endonasal dacryocystorhinostomy (DCR). However, there are conflicting opinions about this

The present study is an up-date metaanalysis to determine whether this adjuvant therapy results in better surgical outcomes in the treatment of primary acquired nasolacrimal duct obstruction

\section{What was learned from the study?}

Intraoperative use of MMC as an adjunctive treatment for external or endonasal DCR is safe and effective in increasing the success rate of the procedure

Despite the favorable results, the evidence was very weak. Thus, further controlled trials with a large sample size are needed to evaluate the optimum concentration as well as exposure time and application mode

\section{INTRODUCTION}

Dacryocystorhinostomy (DCR) is the procedure of choice to treat acquired nasolacrimal duct obstruction (NLDO) $[1,2]$. The surgery can be performed using an external approach (external DCR-Ex-DCR), first described by Toti in 1904, or an endoscopic approach (endoscopic DCR-En-DCR), described by Caldwell in 1893 $[3,4]$.

The chance of success with either Ex-DCR or En-DCR is $>90 \%$ [5]. Failure is frequently related to granulation tissue formation at the osteotomy site or common canaliculus, technical error, or closure of the anastomosis site [6].
Mitomycin-C (MMC) is a chemotherapeutic agent and an alkylating antibiotic derived from Streptomyces caespitosus that inhibits the synthesis of DNA, RNA, and protein. MMC has been used as an adjuvant treatment in DCR since 1998 to prevent excessive scarring and fibrosis causing adhesions in the postoperative period [7]. MMC can inhibit the synthesis and cell proliferation of fibroblasts, reducing the formation of scars and preventing or reducing fibrosis at the operative site $[2,6]$.

The antifibrotic effects of MMC in human nasal mucosal fibroblasts have been well documented in vitro and at the ultrastructural level $[2,4,6,8,9]$. Studies have demonstrated larger osteotomy size in DCR surgery with intraoperative MMC application as adjuvant treatment $[8,10]$. However, according to others, adjuvant use of MMC to prevent failure in Ex-DCR or EnDCR is innocuous and does not change the chance of success of the DCR procedure $[3,11,12]$.

This subject has been the theme of systematic reviews [10, 13-16], including on the use of MMC only in Ex-DCR [13] or only in En-DCR surgeries [14, 15]. Two meta-analyses focused on the use of MMC in Ex-DCR and En-DCR $[10,16]$, but conflicting conclusions were reached.

The present study is an updated meta-analysis including all the current published RCTs involving Ex-DCR and En-DCR with and without MMC to determine whether this adjuvant therapy results in better surgical outcomes in the treatment of primary acquired nasolacrimal duct obstruction (NLDO).

\section{METHODS}

A systematic review and meta-analysis were performed to evaluate the success of En-DCR or Ex-DCR with or without the use of MMC applied as an adjuvant treatment during the surgical procedure for the treatment of primary acquired NLDO. This article is based on previously conducted studies and does not contain any studies with human participants or animals performed by any of the authors. The study protocol was approved by the local Ethics 
Committee on Research in Human Beings of the Medical School-UNESP, Brazil, and recorded in the International Prospective Register of Systematic Reviews (PROSPERO). Verification of the review items was performed according to the PRISMA 2009 checklist.

A comprehensive literature search strategy was performed for the keywords: "dacryocystorhinostomy" and "mitomycin-C" and adapted for each database to achieve more sensitivity. Six databases were searched in this study including SCOPUS, Web of Science, PUBMED, Cochrane Central Register of Controlled Trials (CENTRAL) (The Cochrane Library-latest edition), EMBASE, and LILACS, from 1990 to the cutoff date of October 2019. There was no restriction on language. Additionally, the reference lists of the identified articles were also checked to ensure a thorough search of the literature.

Inclusion criteria in this meta-analysis were randomized clinical trials (RCTs) involving ExDCR or En-DCR comparing outcomes of surgeries with or without the use of MMC. Participants were adult patients with primary acquired NLDO. The intervention group was comprised of patients with primary acquired NLDO who underwent Ex-DCR or En-DCR with the use of mitomycin. The control group was comprised of patients with primary acquired NLDO who underwent Ex-DCR or En-DCR without the use of MMC. All studies included were required to provide the success rates of both the MMC and control groups, and the follow-up time was up to 3 months.

Exclusion criteria were congenital or traumatic obstruction of the lacrimal system, canalicular obstruction, acute dacryocystitis, granulomatous systemic diseases affecting the lacrimal passages, previous lacrimal surgery, DCR using laser, and tumors of the lacrimal sac or paranasal sinuses with secondary obstruction of the lacrimal excretory system.

The primary outcome was surgical success defined as subjective improvement in clinical symptoms, reported by patients, and/or in objective lacrimal system permeability tests, such as the fluorescein dye disappearance test, irrigation of the excretory lacrimal system, dacryocystography, computed tomography scan, and/or visualization of the endoscopic surgical ostium in the nasal cavity. The secondary outcome included adverse effects or complications from the procedure such as fibrosis, obstruction of the surgical ostium, hemorrhage, infection, and granulation or dehiscence observed in the intervention or control groups.

Two reviewers performed the data collection and analysis and independently screened titles and abstracts for eligible studies. Unrelated studies of intraoperative use of MMC during ExDCR or En-DCR or duplicated studies were excluded. Then, a final decision was made on which studies would be included.

Data were collected from eligible studies and summarized using a data extraction sheet especially for this review on the following categories of information: author, publication year, country of publication, number of patients, type of surgical intervention performed (ExDCR or En-DCR), intubation of the lacrimal drainage system with a stent, inclusion criteria, different concentrations, exposure time, mode of administering MMC, monitoring, follow-up, definition, criteria of success, and complications.

The quality of the study was assessed using the "Risk of bias" tool for Cochrane Reviews [17]. This tool uses six separate criteria, each classified according to the standards. Two authors independently assessed the risk of bias in each study, and any disagreement was resolved by discussion or consensus involving all authors.

The statistical analysis was performed using RevMan 5.3 software, provided by the Cochrane Collaboration. The treatment effect and outcomes were measured as dichotomous variables and presented as odds ratio (OR) with 95\% confidence intervals (CI). Clinical heterogeneity was verified by examining the details of the study (different concentrations of MMC and different exposure times for MMC applied), and then the statistical heterogeneity $\left(I^{2}\right)$ between the results was tested using the chi-square and $I^{2}$ value [18]. A fixed-effect model was used for meta-analysis in the absence of heterogeneity $\left(I^{2}=0\right)$. If there was heterogeneity between studies and $I^{2}$ was $>0$, a random-effects model 
was applied [19]. The results were summarized using a forest plot, in which each horizontal line represents an included study. The estimated effect was represented by a square, and the size of the square corresponds to the weight of the study in question. A diamond located at the bottom of the graph represented the combined effect estimate. The principles of GRADE (Grades of Recommendation Assessment, Development, and Evaluation) were used to evaluate the strength of evidence of the primary outcome, and a summary table of findings was constructed using GRADE (Grading of Recommendations Assessment, Development and Evaluation) [20].

\section{RESULTS}

The literature search provided 1028 articles, collected in the bases SCOPUS (639), Web of Science (192), PubMed (113), Cochrane (42), EMBASE (40), and Lilacs (2). Five hundred ninety-two studies were excluded after initial screening because they were duplicated and an additional 543 were excluded evaluating titles and abstracts because they were not relevant to the subject. Of 49 articles that were identified for possible inclusion, 22 were excluded for the following reasons: 7 used other criteria for comparison, 6 were reoperations, 5 were systematic reviews, and 4 were DCRs using a laser technique (Fig. 1).

Thus, 27 clinical trials with only one multicentric study [21] were selected and included in the present meta-analysis. Fourteen studies involved Ex-DCR [6, 8, 11, 22-32] and 13 EnDCR $[4,12,21,33-42]$. The characteristics of the eligible studies are summarized in Table 1. Ten studies were conducted in India $[4,11,21,22,30,33-35,37,42]$, four in Turkey $[6,31,32,36]$, four in China $[26,38,39,41]$, three in Iran $[12,23,28]$, two in Taiwan $[8,27]$, one in Spain [24], one in Saudi Arabia [29], one in Thailand [40], and one in Pakistan [25]. Sample sizes in these studies ranged from 15 to 328 patients. The mean follow-up ranged from 3 to 36 months (Table 1 ).

The number of included surgeries was 2158, with 1099 Ex-DCRs and 1059 En-DCRs. For Ex-
DCR, 550 patients were taking MMC and 549 were not taking MMC; for En-DCR, 534 were taking MMC and 525 were not using MMC (Fig. 2).

The DCR technique was not uniform, and surgeries were not always performed by a single surgeon in many included studies.

The MMC concentration used ranged from 0.2 to $0.5 \mathrm{mg} / \mathrm{ml}$. The $0.2 \mathrm{mg} / \mathrm{ml}$ concentration was used in $11(78.6 \%)[6,8,11,22-24$, 26-28, 30, 32] of 14 studies involving Ex-DCR and in $7(53.8 \%)[4,12,21,34,37,39,41]$ of 13 studies involving En-DCR. Two $(14.3 \%)[25,29]$ Ex-DCR studies did not mention the concentration (Table 1).

Exposure time to MMC in Ex-DCR was from 2 to $30 \mathrm{~min}$. In $7(50 \%)[6,8,22,26-28,32]$ of 14 Ex-DCR studies, MMC was applied for $30 \mathrm{~min}$. Exposure time to MMC in En-DCR varied from 2 to $15 \mathrm{~min}$. In five $(38.5 \%)$ [4, 21, 35, 36, 42] En-DCR studies, MMC was applied for $5 \mathrm{~min}$. Two studies did not mention the exposure time-1 in Ex-DCR [29] and 1 in En-DCR [39] (Table 1).

The application mode was also variable. In most studies, a cotton-tip soaked in MMC was applied in the surgical ostium; one study used irrigation of the lacrimal system with MMC once [30], and another one used MMC socked in artificial tissue in the nasal ostium (Table 1).

Table 2 presents the risk of bias in the included studies of this review. Only a few of the included Ex-DCR or En-DCR studies with and without MMC groups revealed a low risk of bias. The risk of bias analysis was uncertain in most items evaluated.

The success rate was higher in patients who received MMC as an adjuvant treatment to DCR (OR: $2.1 ; 95 \%$ CI $1.52-2.9 ; I^{2}=14 \%$ ). The ExDCR group had higher $I^{2}$ and CI (14 studies; OR: 2.74; 95\% CI $1.54-4.87 ; I^{2}+30 \%$ higher than the group that underwent En-DCR (13 studies; OR: $1.69 ; 95 \%$ CI 1.21-2.37; $I^{2}=0 \%$ ) (Fig. 2).

Table 3 presents the summary of the primary outcome according to GRADE.

The adverse effects or complications observed in the included studies were abnormal bleeding, necrosis, crusts, and granulations and were similar in both groups (with and without the use of MMC). Therefore, it is possible to 


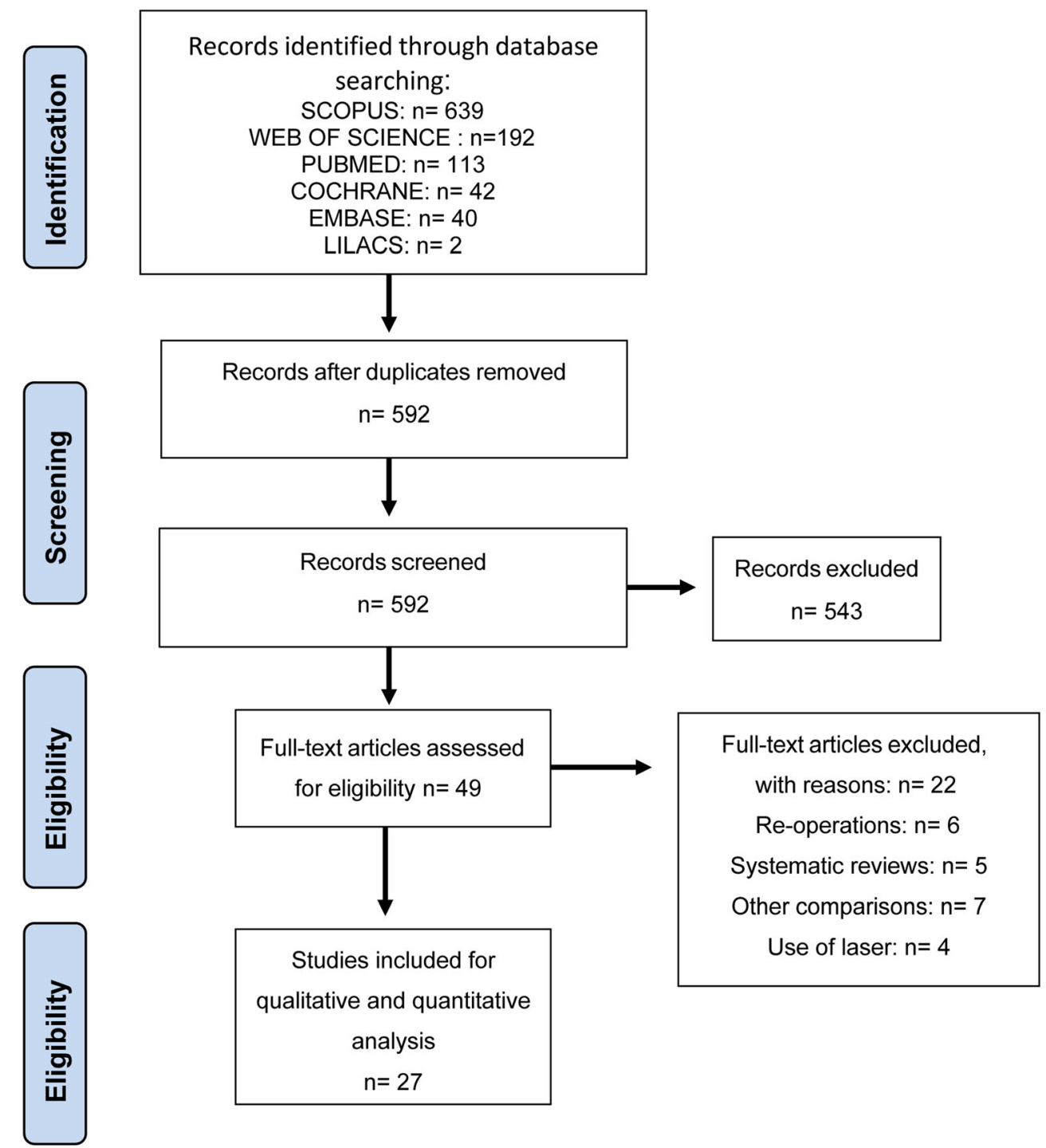

Fig. 1 Data flow diagram of included and excluded studies involving external or endonasal dacryocystorhinostomy surgery with and without mitomycin-C

state that the observed adverse effects are not associated with the use of MMC.

\section{DISCUSSION}

The current meta-analysis indicates a slightly higher chance of success of Ex-DCR or En-DCR with the intraoperative use of MMC. However, in general, the risk of bias is uncertain. The analysis of the isolated studies revealed a significant difference favoring the use of MMC in just one study involving Ex-DCR (OR: 4.24; 95\%
CI 1.35-13.25) [29] and another one involving En-DCR (OR: 11.69; 95\% CI 1.38-99.17) [38], making the evidence very weak mainly because $\mathrm{CI}$ is mostly very high in En-DCR.

MMC is currently in use as an adjuvant treatment to improve success rates in Ex-DCR and En-DCR. Both procedures are well-recognized surgical techniques and are associated with very high success rates, independently of MMC use. However, there are predisposed patients or technical failures inducing fibrosis and secondary obstruction of the surgical 
Table 1 Summary of studies included in the present systematic review of the intraoperative use of MMC as adjuvant treatment in external or endonasal dacryocystorhinostomy

\begin{tabular}{|c|c|c|c|c|c|c|c|c|}
\hline References & Country & Period & Participants & $\begin{array}{l}\text { Concentration } \\
\text { of MMC }\end{array}$ & $\begin{array}{l}\text { Time of } \\
\text { exposure } \\
(\min )\end{array}$ & Intervention & Stent & $\begin{array}{l}\text { Follow- } \\
\text { up } \\
\text { (month) }\end{array}$ \\
\hline $\begin{array}{l}\text { Ahmad and } \\
\text { Hunto [22] }\end{array}$ & India & $\mathrm{NA}$ & $\begin{array}{c}44 \text { (22 MMC/ } \\
22 \text { control) }\end{array}$ & $0.2 \mathrm{mg} / \mathrm{ml}$ & 30 & Ex-DCR & Yes & 9 \\
\hline Ari et al. [6] & Turkey & $2005-2007$ & $\begin{array}{l}100(50 \\
\mathrm{MMC} / 50 \\
\text { control })\end{array}$ & $0.2 \mathrm{mg} / \mathrm{ml}$ & 30 & Ex-DCR & No & 12 \\
\hline $\begin{array}{l}\text { Eshraghy et al. } \\
\text { [23] }\end{array}$ & Iran & $\mathrm{NA}$ & $\begin{array}{c}88 \text { (42 MMC/ } \\
46 \text { control) }\end{array}$ & $0.2 \mathrm{mg} / \mathrm{ml}$ & 15 & Ex-DCR & Yes & 10 \\
\hline $\begin{array}{l}\text { Gonzalvo et al. } \\
{[24]}\end{array}$ & Spain & NA & $\begin{array}{c}17 \text { (9 MMC/8 } \\
\text { control) }\end{array}$ & $0.2 \mathrm{mg} / \mathrm{ml}$ & 2 & Ex-DCR & No & $6-18$ \\
\hline Javaid et al. [25] & Pakistan & 2017 & $\begin{array}{l}200 \\
\quad(100 \mathrm{MMC} / \\
100 \text { control })\end{array}$ & NA & 5 & Ex-DCR & No & 3 \\
\hline Kao et al. [8] & Taiwan & 1994 & $\begin{array}{c}15 \text { (7 MMC/8 } \\
\text { control) }\end{array}$ & $0.2 \mathrm{mg} / \mathrm{ml}$ & 30 & Ex-DCR & Yes & 6 \\
\hline $\mathrm{Li}$ and Zhao [26] & China & NA & $\begin{array}{c}47 \text { (25 MMC/ } \\
22 \text { control) }\end{array}$ & $0.2 \mathrm{mg} / \mathrm{ml}$ & 30 & Ex-DCR & No & 10 \\
\hline Liao et al. [27] & Taiwan & $1995-1998$ & $\begin{array}{c}88 \text { (44 MMC/ } \\
44 \text { control) }\end{array}$ & $0.2 \mathrm{mg} / \mathrm{ml}$ & 30 & Ex-DCR & Yes & 10 \\
\hline Qadir et al. [11] & India & NA & $\begin{array}{c}50 \text { (25MMC/ } \\
25 \text { control })\end{array}$ & $0.2 \mathrm{mg} / \mathrm{ml}$ & 5 & Ex-DCR & No & 6 \\
\hline $\begin{array}{l}\text { Roozitalab et al. } \\
\text { [28] }\end{array}$ & Iran & $2001-2003$ & $\begin{array}{l}130 \\
\text { (65MMC/ } \\
65 \text { control) }\end{array}$ & $0.2 \mathrm{mg} / \mathrm{ml}$ & 30 & Ex-DCR & No & 6 \\
\hline $\begin{array}{l}\text { Shaikh and } \\
\text { Hadrawi [29] }\end{array}$ & $\begin{array}{l}\text { Saudi } \\
\text { Arabia }\end{array}$ & 2013-2014 & $\begin{array}{l}200 \\
(100 \mathrm{MMC} / \\
100 \text { control })\end{array}$ & NA & NA & Ex-DCR & $\mathrm{NA}$ & 3 \\
\hline Sinha et al. [30] & India & NA & $\begin{array}{c}40(20 \mathrm{MMC} / \\
20 \text { control })\end{array}$ & $0.2 \mathrm{mg} / \mathrm{ml}$ & $\begin{array}{l}\text { Irrigation } \\
\text { once }\end{array}$ & Ex-DCR & No & 3 \\
\hline Yalaz [31] & Turkey & $1995-1996$ & $\begin{array}{c}40(20 \mathrm{MMC} / \\
20 \text { control })\end{array}$ & $\begin{array}{c}0.5 \mathrm{mg} / \mathrm{ml} \text { or } \\
1.0 \mathrm{mg} / \mathrm{ml}\end{array}$ & 5 & Ex-DCR & No & $12-18$ \\
\hline
\end{tabular}


Table 1 continued

\begin{tabular}{|c|c|c|c|c|c|c|c|c|}
\hline References & Country & Period & Participants & $\begin{array}{l}\text { Concentration } \\
\text { of MMC }\end{array}$ & $\begin{array}{l}\text { Time of } \\
\text { exposure } \\
(\mathrm{min})\end{array}$ & Intervention & Stent & $\begin{array}{l}\text { Follow-up } \\
\text { (month) }\end{array}$ \\
\hline $\begin{array}{l}\text { Yildirim et al. } \\
\text { [32] }\end{array}$ & Turkey & NA & $\begin{array}{c}40 \text { (20MMC/ } \\
20 \text { control) }\end{array}$ & $0.2 \mathrm{mg} / \mathrm{ml}$ & 30 & Ex-DCR & Yes & $12-19$ \\
\hline $\begin{array}{l}\text { Anisseril et al. } \\
\text { [33] }\end{array}$ & India & $2014-2015$ & $\begin{array}{c}30 \text { (15MMC/ } \\
15 \text { control })\end{array}$ & $0.5 \mathrm{mg} / \mathrm{ml}$ & 2.5 & En-DCR & No & 9 \\
\hline $\begin{array}{l}\text { Farahani and } \\
\text { Ramezani [12] }\end{array}$ & Iran & 2006-2007 & $\begin{array}{c}92(46 \mathrm{MMC} / \\
46 \text { control })\end{array}$ & $0.2 \mathrm{mg} / \mathrm{ml}$ & 3 or 15 & En-DCR & Yes & 12 \\
\hline Ghosh et al. [34] & India & NA & $\begin{array}{c}30(15 \mathrm{MMC} / \\
15 \text { control })\end{array}$ & $0.2 \mathrm{mg} / \mathrm{ml}$ & 2 & En-DCR & No & 12 \\
\hline Gupta et al. [21] & India & 2013-2016 & $\begin{array}{c}80 \text { (40MMC/ } \\
40 \text { control) }\end{array}$ & $0.2 \mathrm{mg} / \mathrm{ml}$ & 5 & En-CR & No & 6 \\
\hline $\begin{array}{l}\text { Kedilaya et al. } \\
\text { [35] }\end{array}$ & India & 2016-2018 & $\begin{array}{l}112 \\
\text { (56MMC/ } \\
56 \text { control) }\end{array}$ & $0.4 \mathrm{mg} / \mathrm{dl}$ & 5 & En-DCR & No & 3 \\
\hline Mudhol et al. [4] & India & $2008-2011$ & $\begin{array}{r}60(30 \mathrm{MMC} \\
/ 30 \text { control })\end{array}$ & $0.2 \mathrm{mg} / \mathrm{ml}$ & 5 & En-DCR & No & 12 \\
\hline $\begin{array}{l}\text { Özkiriş and } \\
\text { Özkiriş [36] }\end{array}$ & Turkey & $2007-2009$ & $\begin{array}{c}54 \text { (28MMC/ } \\
26 \text { control) }\end{array}$ & $0.5 \mathrm{mg} / \mathrm{ml}$ & 5 & En-DCR & Yes & $6-24$ \\
\hline $\begin{array}{l}\text { Prasannaraj et al. } \\
\text { [37] }\end{array}$ & India & $2003-2009$ & $\begin{array}{l}38 \text { (18MMC/ } \\
21 \text { control })\end{array}$ & $0.2 \mathrm{mg} / \mathrm{ml}$ & 10 & En-DCR & No & 6 \\
\hline Qin et al. [38] & China & NA & $\begin{array}{c}73 \text { (39MMC/ } \\
34 \text { control) }\end{array}$ & $0.4 \mathrm{mg} / \mathrm{ml}$ & 3 & En-DCR & Yes & 12 \\
\hline Qiu [39] & China & NA & $\begin{array}{l}328 \\
\quad(162 \mathrm{MMC} / \\
162 \text { control })\end{array}$ & $0.2 \mathrm{mg} / \mathrm{ml}$ & NA & En-DCR & Yes & $3-36$ \\
\hline $\begin{array}{l}\text { Tirakunwichcha } \\
\text { et al. }[40]\end{array}$ & Thailand & 2004-2008 & $\begin{array}{c}50 \text { (26MMC/ } \\
24 \text { control) }\end{array}$ & $0.5 \mathrm{mg} / \mathrm{ml}$ & 3 & En-DCR & Yes & 12 \\
\hline Xie et al. [41] & China & NA & $\begin{array}{c}62 \text { (31MMC/ } \\
31 \text { control) }\end{array}$ & $0.2 \mathrm{mg} / \mathrm{ml}$ & 10 & En-DCR & No & 6 \\
\hline $\begin{array}{l}\text { Wadhera et al. } \\
\text { [42] }\end{array}$ & India & NA & $\begin{array}{c}50(25 \mathrm{MMC} / \\
25 \text { control })\end{array}$ & $0.5 \mathrm{mg} / \mathrm{ml}$ & 5 & En-DCR & No & 12 \\
\hline
\end{tabular}

$M M C$ mitomycin-C, $m g / m l$ milligrams per milliliter, $N A$ not available, $E x-D C R$ external DCR, En-DCR endoscopic DCR 


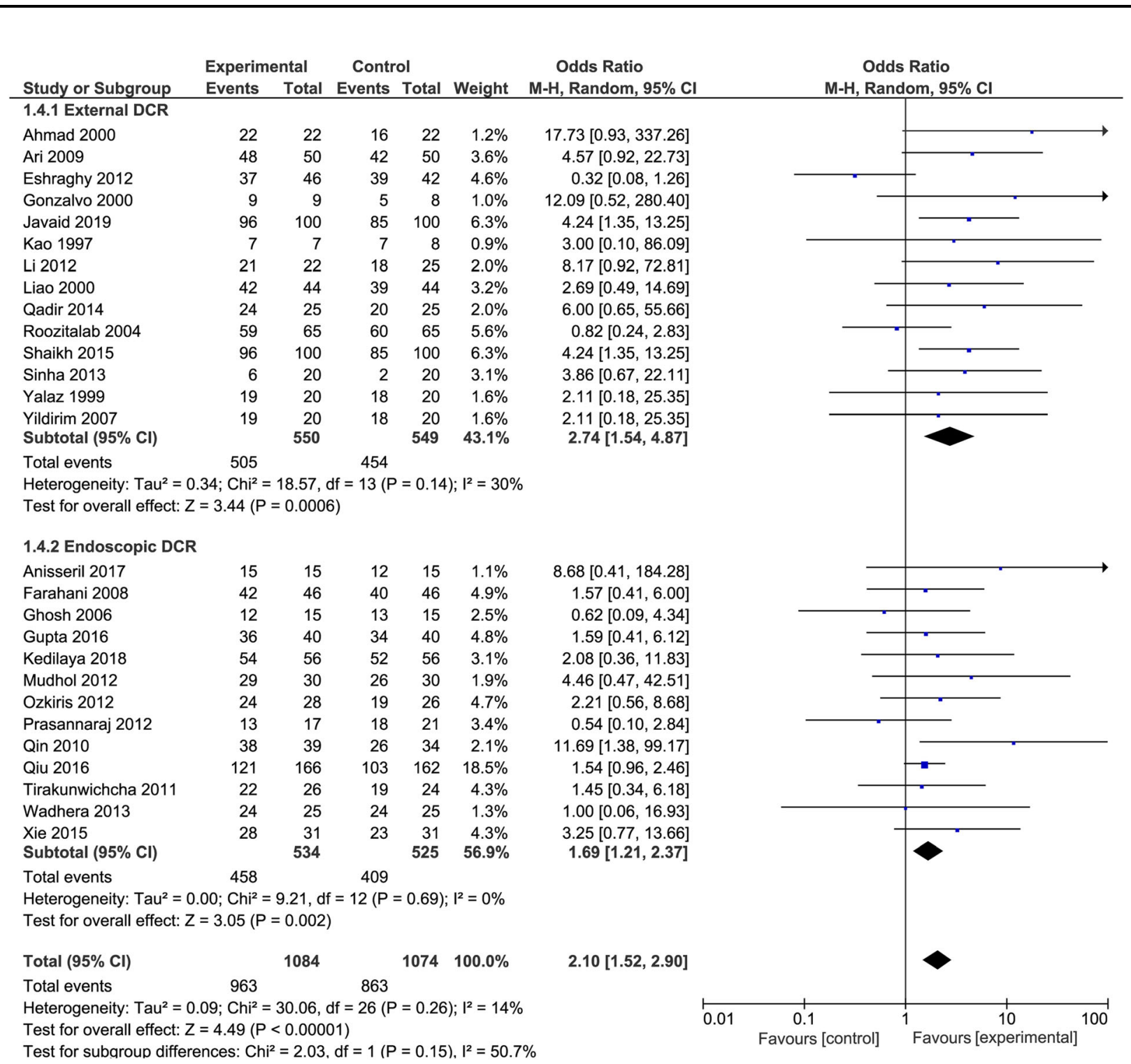

Fig. 2 Forest plot in external or endonasal dacryocystorhinostomy surgery with and without mitomycin-C

ostium. Especially in these cases, it is important to have an adjuvant treatment to improve surgical success. However, the majority of studies about this subject include patients with no restrictions.

The current metanalysis just involved primary acquired NLDO cases. However, the failure rates of primary EX-DCR, primary EN-DCR, and revision EN-DCR in the absence of MMC were $12.6 \%, 18.3 \%$, and $30.4 \%$, respectively [16], reinforcing that MMC would be more necessary in cases of recurrence of obstruction.
The current meta-analysis evaluated the largest number of databases and included the largest number of studies, analyzing many more procedures with their respective outcomes. However, the extensive search in databases just revealed 27 articles out of the 1028 studies that met the inclusion criteria for this systematic review. Of the included studies, the number of patients submitted to Ex-DCR was slightly lower than that submitted to En-DCR. However, the number of subjects who received MMC in ExDCR (14 studies) $[6,8,11,22-32]$, as well as in 
Table 2 Risk of bias in studies included in this meta-analysis on the intraoperative use of MMC as adjuvant treatment in external or endonasal dacryocystorhinostomy

\begin{tabular}{|c|c|c|c|c|c|c|}
\hline References & $\begin{array}{l}\text { Random } \\
\text { sequence } \\
\text { generation }\end{array}$ & $\begin{array}{l}\text { Allocation } \\
\text { concealment }\end{array}$ & $\begin{array}{l}\text { Blinders of } \\
\text { participants and } \\
\text { professionals }\end{array}$ & $\begin{array}{l}\text { Blindness of } \\
\text { outcome } \\
\text { evaluators }\end{array}$ & $\begin{array}{l}\text { Incomplete } \\
\text { outcome }\end{array}$ & $\begin{array}{l}\text { Selective } \\
\text { outcome } \\
\text { report }\end{array}$ \\
\hline $\begin{array}{l}{ }^{*} \text { Ahmad and } \\
\text { Hunto [22] }\end{array}$ & Uncertain & Uncertain & Low & High & Uncertain & Uncertain \\
\hline${ }^{*}$ Ari et al. [6] & Low & Uncertain & Low & Low & Low & Low \\
\hline $\begin{array}{l}\text { *Eshraghy et al. } \\
\text { [23] }\end{array}$ & Uncertain & Uncertain & Uncertain & Uncertain & Uncertain & Uncertain \\
\hline $\begin{array}{l}{ }^{*} \text { Gonzalvo et al. } \\
\text { [24] }\end{array}$ & Uncertain & Uncertain & Uncertain & Uncertain & Uncertain & Uncertain \\
\hline${ }^{*}$ Javaid et al. [25] & Uncertain & Uncertain & Uncertain & Uncertain & Low & Low \\
\hline${ }^{*}$ Kao et al. $[8]$ & High & High & Uncertain & Uncertain & Uncertain & Uncertain \\
\hline${ }^{*}$ Li and Zhao [26] & High & Uncertain & High & Uncertain & Uncertain & Uncertain \\
\hline${ }^{*}$ Liao et al. [27] & Uncertain & Uncertain & Low & High & Uncertain & Uncertain \\
\hline${ }^{*}$ Qadir et al. [10] & High & High & Uncertain & Uncertain & Uncertain & Uncertain \\
\hline $\begin{array}{l}\text { *Roozitalab et al. } \\
\quad[28]\end{array}$ & High & High & Uncertain & Uncertain & Uncertain & Uncertain \\
\hline $\begin{array}{l}\text { *Shaikh and } \\
\text { Hadrawi [29] }\end{array}$ & High & High & Uncertain & Uncertain & Uncertain & Uncertain \\
\hline${ }^{*}$ Sinha et al. [30] & High & High & Uncertain & High & Uncertain & Uncertain \\
\hline${ }^{*}$ Yalaz [31] & Uncertain & Uncertain & Uncertain & Uncertain & Uncertain & Uncertain \\
\hline $\begin{array}{l}\text { *Yildirim et al. } \\
\quad[32]\end{array}$ & Uncertain & Uncertain & Low & Low & Uncertain & Uncertain \\
\hline $\begin{array}{l}{ }^{\#} \text { Anisseril et al. } \\
{[33]}\end{array}$ & Low & Uncertain & Low & Low & Low & Uncertain \\
\hline $\begin{array}{l}{ }^{\#} \text { Farahani and } \\
\text { Ramezani [11] }\end{array}$ & Low & Incerto & Low & Low & Low & Uncertain \\
\hline${ }^{\#}$ Ghosh et al. [34] & Uncertain & Uncertain & Uncertain & Uncertain & Uncertain & Uncertain \\
\hline${ }^{\#}$ Gupta et al. [21] & High & Uncertain & Uncertain & Uncertain & Uncertain & Uncertain \\
\hline $\begin{array}{l}{ }^{\#} \text { Kedilaya et al. } \\
{[35]}\end{array}$ & Uncertain & Uncertain & Uncertain & Uncertain & Low & Low \\
\hline${ }^{\#}$ Mudhol et al. [4] & Low & Uncertain & Uncertain & Uncertain & Uncertain & Uncertain \\
\hline $\begin{array}{l}\text { \#Özkiriş and } \\
\text { Özkiriş [36] }\end{array}$ & Uncertain & Uncertain & Uncertain & Uncertain & Uncertain & Uncertain \\
\hline $\begin{array}{l}\text { \#Prasannaraj et al. } \\
\text { [37] }\end{array}$ & Low & Low & Uncertain & Uncertain & Uncertain & Uncertain \\
\hline
\end{tabular}


Table 2 continued

\begin{tabular}{|c|c|c|c|c|c|c|}
\hline References & $\begin{array}{l}\text { Random } \\
\text { sequence } \\
\text { generation }\end{array}$ & $\begin{array}{l}\text { Allocation } \\
\text { concealment }\end{array}$ & $\begin{array}{l}\text { Blinders of } \\
\text { participants and } \\
\text { professionals }\end{array}$ & $\begin{array}{l}\text { Blindness of } \\
\text { outcome } \\
\text { evaluators }\end{array}$ & $\begin{array}{l}\text { Incomplete } \\
\text { outcome }\end{array}$ & $\begin{array}{l}\text { Selective } \\
\text { outcome } \\
\text { report }\end{array}$ \\
\hline${ }^{\#}$ Qin et al. [38] & Uncertain & Low & High & High & Uncertain & Uncertain \\
\hline${ }^{\#}$ Qiu [39] & Uncertain & Uncertain & Uncertain & Uncertain & Uncertain & Uncertain \\
\hline $\begin{array}{l}{ }^{\#} \text { Tirakunwichcha } \\
\text { et al. }[40]\end{array}$ & Low & Low & Low & Low & Uncertain & Uncertain \\
\hline${ }^{\#}$ Xie et al. [41] & High & High & Uncertain & Uncertain & Uncertain & Uncertain \\
\hline $\begin{array}{l}{ }^{\#} \text { Wadhera et al. } \\
{[42]}\end{array}$ & High & High & Uncertain & Low & Uncertain & Uncertain \\
\hline
\end{tabular}

* Study related to Ex-DCR

\# Study related to En-DCR

En-DCR (13 studies) [4, 12, 21, 33-42], was similar in both techniques.

The clinical heterogeneity is considered the major disadvantage of all the clinical studies. Multiple factors such as racial variations, age, and sex of the patient can also affect the eventual outcome of the surgery. All the published RTCs about MMC effects in DCR except five $[6,24,31,32,36]$ are from the Middle East $[12,23,25,28,29]$ or Asia $[4,8$, $11,21,22,26,27,30,33,34,35,37$, $38,39,40,41,42]$ inducing a possible racial component variation in the performed metanalysis.

In the case of MMC, several other factors might affect the results, such as concentration, exposure time, and application method. The concentration of MMC varied from one study to another, reflecting the uncertainty over the optimal dosage required. A concentration of $0.2 \mathrm{mg} / \mathrm{ml}$ was the most used in Ex$[6,8,11,22-24,26-28,30,32]$ or En-DCR $[4,12,21,34,37,39,41]$, with some studies using a concentration of $0.5 \mathrm{mg} / \mathrm{ml}$ in $\mathrm{Ex}$ [31] or in En-DCR [33, 36, 40, 42]. The concentration of $0.4 \mathrm{mg} / \mathrm{ml}$ was applied in two studies involving En-DCR $[35,38]$. Two Ex-DCR studies did not mention the concentration $[25,29]$. There are reports about similar results using 0.2 or $0.5 \mathrm{mg}$ / $\mathrm{ml}$ [43] and the disadvantage of using concentrations $>1 \mathrm{mg} / \mathrm{ml} \mathrm{[10].}$
The exposure time of the tissues to MMC during intraoperative application was also variable. In Ex-DCR the exposure time varied from 2 to $30 \mathrm{~min}$, and the majority of authors used MMC for 30 min [6, 8, 22, 26-28, 32]. However, in En-DCR the exposure time was shorter with only one study using from 3 to $15 \mathrm{~min}$ [12] and the majority using within $5 \mathrm{~min}$ $[4,21,35,36,42]$. The risk of accidental skin contact in Ex-DCR or with other nasal structures in En-DCR can be higher with extended exposure time [10] and must be avoided.

The MMC application method at the operative ostium can also be variable in the studies, e.g., over the osteotomy or on the nasal mucosa, using cotton tips, soaking, or irrigation. MMC effectiveness can be reduced by factors such as profuse bleeding "washing" the MMC from the application site or technical difficulties in applying the MMC in the appropriate area, especially in En-DCR [10]. Other elements, including the fact that some surgeons prefer to wash off the MMC after application while others do not; surgical DCR technical variability, such as the use of different types of flaps or the use of different kinds of stiches in Ex-DCR; and surgeon expertise, since a beginner is more likely to traumatize the nasal mucosa or the nasal septum resulting in more septal adhesions, are also confounders, including the parameters to judge the final outcome [2]. 


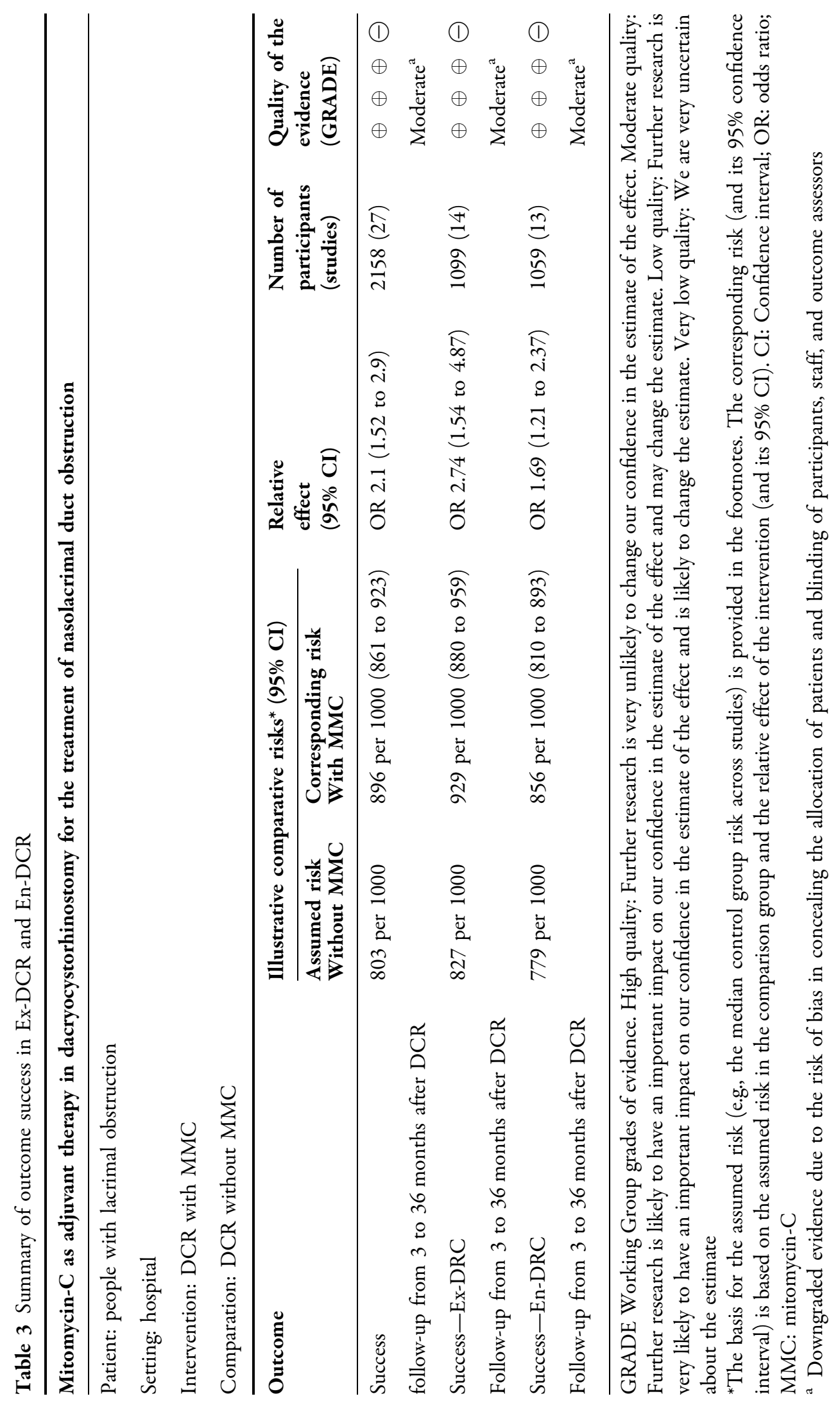


Thus, optimal dosage, exposure time, and MMC application methods are not homogeneous. The decisions about these parameters are often arbitrary or based on the clinical experience of the surgeon and can alter the outcome.

Another confounding factor is the use of MMC in addition to stents, making it difficult to recognize what the effect of each would be separately since both are considered adjuvant treatment to improve results in DCR [5].

In the current metanalysis, stents were not placed in the majority of Ex$[6,11,24-26,28,30,31]$ and En-DCR procedures $[4,21,33-35,37,41,42]$. However, another metanalysis showed MMC can improve the results of DCR with or without stents [10], and MMC associated with stents can favor results of En-DCR but not of Ex-DCR [44], with weak evidence. Therefore, the use of stents in DCR is still controversial, with some studies reporting stents can increase the patency of the tear drainage [45] and others reporting worsening outcomes with the use of stents [46] or similar results with or without stents [13].

After surgery, the surgical ostium can have a natural tendency to size reduction [10]. Because of this, the follow-up period must be adequate and based on the healing process. However, there is no consensus about this point, with authors suggesting 7.5 weeks, ranging from 6 to 12 months or more $[21,37,46]$. We included studies with at least 3 months of follow-up based on our personal experience, which showed that at 2 months there is healing stability after DCR. However, long-term follow-up is necessary mainly in young patients and revision DCR because of the tendency to a higher failure rate [47].

The present study revealed that intraoperative use of MMC in the surgical site as an adjuvant treatment may have favorable results, increasing the chance of success in Ex- or EnDCR as reported by others $[10,16]$. The unfavorable results obtained with intraoperative MMC in Ex-DCR can be speculatively explained by dehiscence of sutures of flaps between the lacrimal sac and the nasal mucosa secondary to delayed healing, worsening the result and explaining less evidence in the case of Ex-DCR. However, the effect of MMC in the nasal mucosa and clinical efficacy after application of MMC are directly dependent on the cytostatic concentration of the drug on the tissues [9].

Additionally, our metanalysis revealed the use of MMC does not increase the adverse effects such as abnormal nasal bleeding, mucosal necrosis, or infection $[4,27]$.

There are limitations to our meta-analysis. We evaluated only adults with primary acquired NLDO, but some authors evaluated En-DCR revision surgery [16] or primary and revision Exand En-DCR cases, reporting differences [16] or no statistical difference between groups [10]. There is a risk of bias, especially because of uncertain allocation and no blindness in most studies. Additionally, the variable concentration, timing, and mode of application of MMC and the combined use of stents can alter the results.

The strengths of this study are having the largest number of databases evaluated, including many randomized clinical trials following strict criteria, with analysis of the most cases/surgeries and adequate follow-up time, factors considered important to assess and reinforce the outcome.

\section{CONCLUSION}

In conclusion, intraoperative use of MMC as an adjunctive treatment for Ex- or En-DCR is safe and effective in increasing the success rate of the procedure. Despite the favorable results, the evidence was very weak. Thus, further controlled trials with large sample sizes are needed to evaluate the optimum concentration as well as exposure time and application mode.

\section{ACKNOWLEDGEMENTS}

The authors are grateful to the librarian Marluci Betini for helping to survey the references included in this study.

Funding. This study has no formal sponsorship, and funding was not received for this study or publication of this article. 
Authorship. All named authors meet the International Committee of Medical Journal Editors (ICMJE) criteria for authorship for this article, take responsibility for the integrity of the work as a whole, and have given their approval for this version to be published.

Disclosures. Tamata T.S. Sousa, Silvana A. Schellini, Roberta L.F.S. Meneghim, and Antonio J.M. Cataneo declare no personal, financial, commercial, or academic conflicts of interest, and none of the authors have a financial or proprietary interest in a product, method, or material in this paper.

Compliance with Ethics Guidelines. This article is based on previously conducted studies and does not contain any studies with human participants or animals performed by any of the authors. The study protocol was approved by the local Ethics Committee on Research in Human Beings of the Medical School-UNESP, Brazil, and recorded in the International Prospective Register of Systematic Reviews (PROSPERO). Verification of the review items was performed according to the PRISMA 2009 checklist.

Data Availability. The datasets analyzed in the current study are available from the corresponding author on reasonable request.

Open Access. This article is licensed under a Creative Commons Attribution-NonCommercial 4.0 International License, which permits any non-commercial use, sharing, adaptation, distribution and reproduction in any medium or format, as long as you give appropriate credit to the original author(s) and the source, provide a link to the Creative Commons licence, and indicate if changes were made. The images or other third party material in this article are included in the article's Creative Commons licence, unless indicated otherwise in a credit line to the material. If material is not included in the article's Creative Commons licence and your intended use is not permitted by statutory regulation or exceeds the permitted use, you will need to obtain permission directly from the copyright holder. To view a copy of this licence, visit http://creativecommons.org/licenses/by$\mathrm{nc} / 4.0 /$.

\section{REFERENCES}

1. Yakopson VS, Flanagan JC, Ahn D, Luo BP. Dacryocystorhinostomy: history, evolution and future directions. Saudi J Ophthalmol. 2011;25(1):37-49.

2. Nair PG, Ali MJ. Mitomycin-C in dacryocystorhinostomy: from experimentation to implementation and the road ahead: a review. Indian J Ophthalmol. 2015;63(4):335-9.

3. Zilelioğlu G, Uğurbaş SH, Anadolu Y, Akiner MAT. Adjunctive use of mitomycin $\mathrm{C}$ on endoscopic lacrimal surgery. Br J Ophthalmol. 1998;82(1):63-6.

4. Mudhol RR, Zingade ND, Mudhol RS, Harugop AS, Das AT. Prospective randomized comparison of mitomycin $\mathrm{C}$ application in endoscopic and external dacryocystorhinostomy. Indian J Otolaryngol Head Neck Surg. 2013;65(Suppl2):255-9.

5. Syed MI, Hendry JCAW. Endonasal dacryocystorhinostomy with and without stenting. Ann $\mathrm{R}$ Coll Surg Engl. 2014;96(2):173-4.

6. Ari S, Gun R, Surmeli S, Atay AE, Caca I. Use of adjunctive mitomycin $\mathrm{C}$ in external dacryocystorhinostomy surgery compared with surgery alone in patients with nasolacrimal duct obstruction: a prospective, double-masked, randomized, controlled trial. Curr Ther Res Clin Exp. 2009;70(4): 267-73.

7. Ugurbas SH, Zilelioglu G, Sargon MF, Anadolu Y, Akiner M, Aktürk T. Histopathologic effects of mitomycin-C on endoscopic transnasal dacryocystorhinostomy. Ophthalmic Surg Lasers. 1997;28: 300-4.

8. Kao SCS, Liao CL, Tseng JHS, Chen MS, Hou PK. Dacryocystorhinostomy with intraoperative mitomycin C. Ophthalmology. 1997;104(1):86-91.

9. Atkova IEL, Fedorov AA, Root AO, Iartsev SD, Krakhovetsky NN, Yartsev VD. Causes of unsatisfactory results of the use of mitomycin-C in endoscopic endonasal dacryocystorhinostomy. Saudi J Ophthalmol. 2017;31:150-5.

10. Qian Z, Zhang Y, Fan X. Clinical outcomes of dacryocystorhinostomy with or without intraoperative use of mitomycin c: a systematic review and meta-analysis. J Ocul Pharmacol Ther. 2014;30(8): 615-24. 
11. Qadir M, Ahangar A, Dar MA, Hamid SKM. Comparative study of dacryocystorhinostomy with and without intraoperative application of Mitomycin C. Saudi J Ophthalmol. 2014;28(1):44-8.

12. Farahani F, Ramezani A. Effect of intraoperative mitomycin $\mathrm{C}$ application on recurrence of endoscopic dacryocystorhinostomy. Saudi Med J. 2008;29(9):1354-6.

13. Feng YF, Yu JG, Shi JL, Huang JH, Sun YL, Zhao YE. A meta-analysis of primary external dacryocystorhinostomy with and without mitomycin C. Ophthal Epidemiol. 2012;19:364-70.

14. Feng YF. Efficacy of Mitomycin C in Endoscopic Dacryocystorhinostomy: a systematic review and meta-analysis. ClinicalTrials.gov. 2011. Available: https:/clinicaltrials.gov/ct2/show/

NCT01772277?term=NCT017722771. Accessed 2013 Jan 18.

15. Cheng S, Feng Y, Xu L, Li YHJ. Efficacy of mitomycin $\mathrm{C}$ in endoscopic dacryocystorhinostomy: a systematic review and meta-analysis. PLoS ONE. 2013;8(5):e62737.

16. Xue $\mathrm{K}$, Mellington FENJ. Meta-analysis of the adjunctive use of mitomycin in primary and revision, external and endonasal dacryocystorhinostomy. Orbit. 2014;33(4):239-44.

17. Higgins JPT, Altman DGSJ. Assessing risk of bias in included studies. In: Green S, editor. Cochrane handbook for systematic reviews of interventions. Chinchester: John Wiley \& Sons Ltd; 2011. p. 649. https://doi.org/10.1002/9780470712184.ch8.

18. Deeks JJ, Higgins JPTAD. Analysing data and undertaking meta-analyses. In: Thomas J, Chandler J, Cumpston M, Li T, Page MJ, Welch VA, editors. Cochrane handbook for systematic reviews of interventions. Chinchester: John Wiley \& Sons Ltd; 2019. p. 187-241. https://doi.org/10.1002/ 9781119536604.

19. Mantel N, Haenszel W. Statistical aspects of the analysis of data from retrospective studies of disease. J Natl Cancer Inst. 1959;22:719-48.

20. Guyatt GH, Oxman AD, Kunz R, Vist GE, Falck-Ytter YSH. GRADE working group. What is "quality of evidence" and why is it important to clinicians? BMJ. 2008;336:995-8.

21. Gupta R, Purohit JP, Bhan C, Sinha I. Endoscopic dacryocystorhinostomy with and without intraoperative Mitomycin-C: a comparative study. J Evol Med Dent Sci. 2016;5(33):1819-21.
22. Ahmad SS, Unto RA. Results of intraoperative mitomycin C application in dacryocystorhinostomy. JK Sci. 2002;4(1):27-31.

23. Eshraghy B, Raygan F, Tabatabaie SZ, Tari AS, Kasaee A, Rajabi MT. Effect of mitomycin c on success rate in dacryocystorhinostomy with silicone tube intubation and improper flaps. Eur J Ophthalmol. 2012;22(3):326-9.

24. Gonzalvo-Ibáñez FJ, Fuertes-Fernández IF, Tirado FJ, Delgado H, Arbues R, Lopez H. External dacryocystorhinostomy with mitomycin $\mathrm{C}$. Clinical and anatomical evaluation with helical computed tomography. Arch Soc Esp Oftalmol. 2000;75: 611-7.

25. Javaid A, Arif A, Butt MN. Whether intraoperative mitomycin-c (MMC) usage is effective or not? a comparative research conducted on chronic dacryocystitis patients undergoing external dacryocystorhinostomy (EXT-DCR). Indo Am J Pharmaceut Sci. 2019;6(2):2821-4.

26. Li H, Zhao YZJ. Application of mitomycin $\mathrm{C}$ in nasal endoscopic dacryocystorhinostomy. Int Eye Sci. 2012;3:568-9.

27. Liao SL, Kao SC, Tseng JH, Chen MS, Hou PK. Results of intraoperative mitomycin $\mathrm{C}$ application in dacryocystorhinostomy. $\mathrm{Br} \mathrm{J}$ Ophthalmol. 2000;84:903-6.

28. Roozitalab MH, Amirahmadi M, Namazi MR. Results of the application of intraoperative mitomycin C in dacryocystorhinostomy. Eur J Ophthalmol. 2004;14(6):461-3.

29. Shaikh RM, DE Hadrawi MT. Comparison of success rate of external dacryocystorhinostomy with and without mitomycin-c in patients of chronic dacryocystitis. Pakistan J Med Heal Sci. 2015;9(3):934-6.

30. Sinha M, Bajaj M, Pushker N, Ghose SCM. Efficacy of probing with Mitomycin-C in adults with primary acquired nasolacrimal duct obstruction. J Ocul Pharmacol Ther. 2013;29(3):353-5.

31. Yalaz MHZ. Use of mitomycin $\mathrm{C}$ and 5-fluorouracil in external dacryocystorhinostomy. Orbit. 1997;18(4):239-45.

32. Yildirim C, Yaylali V, Esme A, Ozden S. Long-term results of adjunctive use of mitomycin $\mathrm{C}$ in external dacryocystorhinostomy. Int Ophthalmol. 2007;27(1):31-5.

33. Anisseril A, Reghunathan D, Edacheriyan B, Mukundan A, Rajesh KP, Shaharbana B. Endoscopic dacryocystorhinostomy with or without intraoperative application of mitomycin C. J Evol Med Dental Sci. 2017;6(66):4773-8. 
34. Ghosh S, Roychoudhury A, Roychaudhuri BK. Use of mitomycin C in endo-DCR. Indian J Otolaryngol Head Neck Surg. 2006;58(4):368-9.

35. Kedilaya YJ, Chacko A, Poorey VK. Improving the results of endonasal dacryocystorhinostomy with mitomycin C application: a prospective case-control study. Indian J Otolaryngol Head Neck Surg. 2018;70(4):477-81.

36. Özkiriş M, Özkiriş A. Endoscopic dacryocystorhinostomy not using canalicular silicone intubation tube with and without mitomycin C: a comparative study. Eur J Ophthalmol. 2012;22(3):320-5.

37. Prasannaraj T, Kumar BYP, Narasimhan I, Shivaprakash KV. Significance of adjunctive mitomycin $\mathrm{C}$ in endoscopic dacryocystorhinostomy. Am J Otolaryngol - Head Neck Med Surg. 2012;33(1): 47-50.

38. Qin ZY, Lu ZM, Liang Z. Application of mitomycin $\mathrm{C}$ in nasal endoscopic dacryocystorhinostomy. Int J Opbthalmol. 2010;10:1569-71.

39. Qui S-Q. Clinical observation of mitomycin C used in nasal endoscopic dacryocystorhinostomy. Int Eye Sci. 2016;16:166-8.

40. Tirakunwichcha S, Aeumjaturapat S, Sinprajakphon S. Efficacy of mitomycin C in endonasal endoscopic dacryocystorhinostomy. 2011;121(2):433-6.

Laryngoscope.

41. Xie P, Ouyang J, He J. Clinical observation of endoscopic dacryocystorhinostomy on the treatment of recurrent chronic dacryocystitis. Int Eye Sci. 2015;67:7-8.

42. Wadhera R, Gulati SP, Khurana AK, Sharma H, Kalra V, Ghai A. A comparative study of endoscopic endonasal dacryocystorhinostomy with and without intraoperative mitomycin-C application. Clin Rhinol. 2013;6(1):5-9.

43. You YA, Fang CT. Intraoperative mitomycin C in dacryocystorhinostomy. Ophthal Plast Reconstr Surg. 2001;17:172-7.

44. Orsolini MJ, Schellini SA, Meneguim RLFS, Catâneo AJM. Success of endoscopic dacryocystorhinostomy with or without stents: systematic review and metaanalysis. Orbit. Online Oct 2019. 1-8p.

45. Pandya VB, Lee S, Benger R, Danks JJ, Kourt G, Martin PA, Lertsumitkul S, McCluskey P, Ghabrial R. External dacryocystorrhinostomy: assessing factors that influence outcome. Orbit. 2010;29:291-7.

46. Woog JJ, Kennedy RH, Custer PL, Kaltreider SA, Meyer DR, Camara JG. Endonasal dacryocystorhinostomy: a report by the American Academy of ophthalmology. Ophthalmology. 2001;108: 2369-77. https://doi.org/10.1080/01676830.2019. 1677726 .

47. Marcet MM, Kuk AK, Phelps PO. Evidence-based review of surgical practices in endoscopic endonasal dacryocystorhinostomy for primary acquired nasolacrimal duct obstruction and other new indications. Cur Opin Ophthalmol. 2014;25:443-8. 